\title{
Immunohistochemical analysis of collagen content and types in the rectus abdominis muscle of cadavers of different ages ${ }^{1}$
}

\author{
Imunohistoquímica do colágeno no músculo reto do abdome de cadáveres de diferentes \\ grupos etários
}

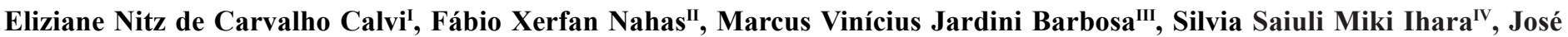
Augusto Calil ${ }^{\mathrm{V}}$, Lydia Masako Ferreira ${ }^{\mathrm{VI}}$

IFellow PhD degree, Division of Plastic Surgery, UNIFESP. Associate Professor, Department of Physical Therapy, UNINOVE, Sao Paulo-SP, Brazil. Responsible for intellectual, scientific content of the study and critical revision.

IIPhD, Associate Professor, Division of Plastic Surgery, UNIFESP, Sao Paulo-SP, Brazil. Mentor of Fellow PhD degree Eliziane Nitz de Carvalho Calvi. Responsible for conception of the scientific content with supervision of all phases of the study, manuscript writing and critical revision.

IIIPhD, Volunteer Faculty, Division of Plastic Surgery, UNIFESP, Sao Paulo-SP, Brazil. Helped with technical procedures and collection of study.

${ }^{\mathrm{IV}} \mathrm{PhD}$, Associate Professor, Department of Pathology, UNIFESP, Sao Paulo-SP, Brazil. Macroscopic and histopathological examinations.

${ }^{v} \mathrm{PhD}$, Member of the Brazilian Society of Plastic Surgery. Helped with technical procedures and collection of study.

viPhD, MBA, Chairwoman, Full Professor, Division of Plastic Surgery, Head of the Department of Surgery, UNIFESP, Sao Paulo-SP, Brazil. Manuscript writing and critical revision.
\end{abstract}

\section{ABSTRACT \\ PURPOSE: To assess the collagen content and types in the rectus abdominis muscle of cadavers of different ages.}

METHODS: Forty fresh adult male cadavers, at room temperature, were obtained from the Institute of Legal Medicine of Franca and dissected within 24 hours of death. The cadavers were divided into two groups: Group A ( $\mathrm{n}=20), 18$ to 30 years of age, and Group B $(\mathrm{n}=20), 31$ to 60 years of age. Bilateral incisions were made in the middle portion of anterior rectus sheath $3 \mathrm{~cm}$ superiorly and $2 \mathrm{~cm}$ inferiorly to the umbilicus and four fragments of the rectus abdominis muscle were dissected. The samples were fixed in $10 \%$ buffered formalin and sent for immunohistochemical analysis to determine collagen content and types.

RESULTS: Immunohistochemical results revealed higher amounts of type I and type III collagen in Group A. However, no difference in the amount of type IV collagen was found between the groups.

CONCLUSION: The amount of type I and type III collagen was higher in group A.

Key words: Collagen. Rectus Abdominis. Age Groups. Cadaver.

\section{RESUMO}

OBJETIVO: Avaliar o colágeno no músculo reto do abdome em cadáveres de diferentes faixas etárias.

MÉTODOS: Foram dissecados 40 cadáveres adultos masculinos, não fixados, com tempo de óbito de até 24 horas, em temperatura ambiente, provenientes do Instituto Médico-Legal de Franca (SP - Brasil). Os cadáveres foram distribuídos em dois grupos: GRUPO A ( $(n=20)-18$ a 30 anos e GRUPO B $(n=20)-31$ a 60 anos. Realizou-se incisão na porção mediana da lâmina anterior da bainha do músculo reto a $3 \mathrm{~cm}$ superiormente e $2 \mathrm{~cm}$ inferiormente ao umbigo em ambos os lados, sendo retirados quatro fragmentos de músculo reto do abdome. Esse material foi conservado em formalina tamponado a $10 \%$ e enviado para imuno-histoquímica para determinação do tipo de colágeno.

RESULTADOS: Na Imunihistoquímica os colágenos I e III foram estatisticamente maiores no grupo A, porém não houve diferença entre os grupos em relação ao colágeno IV.

CONCLUSÃO: A quantidade de colágeno tipo I e III foi maior no grupo A.

Descritores: Colágeno. Reto do Abdome. Grupos Etários. Cadáver. 


\section{Introduction}

The most common defects of the abdominal wall are incisional hernias, tumor resections, trauma, congenital defects, and deformities resulting from the transposition of the rectus abdominis muscle, especially in breast reconstruction ${ }^{1}$. The incidence of these defects is high, with more than $11 \%$ of patients who undergo median laparotomy developing incisional hernias ${ }^{2}$. Up to $27 \%$ of patients who undergo breast reconstruction with a rectus abdominis muscle flap may develop donor-site bulging ${ }^{3}$. Incisional hernia formation may be related to local or systemic changes, which may compromise the healing process ${ }^{4,5}$. Although most incisional hernias are asymptomatic, they are associated with pain, incarceration, or strangulation in about $30 \%$ of the cases. Additionally, incisional hernia is the most common indication for reoperation after laparotomy ${ }^{6}$.

Collagen is an important component of fasciae and muscles that provides resistance to these structures ${ }^{7}$. At present, 19 types of collagen have been described ${ }^{8}$, with the types I, II and III being the most studied ones. Collagens type I, III, IV and V are found in striated muscles and only type I and III are found in fasciae ${ }^{7}$. Type I collagen is the most common and accounts for $90 \%$ of the total collagen in mammals. It is synthesized by fibroblasts, odontoblast, and osteoblasts and is usually organized into thick bundles, which confer resistance to structures. Type III collagen is composed of three alpha-1 chains and forms shorter and thinner fibers. It is synthesized by fibroblasts and reticular cells, and generally found associated with type I collagen in different ratios. Type III collagen is prevalent in tissues that require some degree of elasticity, such as the skin, muscles, fasciae, and ligaments. Type $\mathrm{V}$ collagen regulates the diameter of collagen fibers ${ }^{9}$. Fachinelli ${ }^{10}$ reported that the amount of total collagen was $18.05 \%$ lower in the aponeurosis of cadavers with anterior abdominal wall hernias than in that of cadavers without hernia, and that the amounts of type I and type III collagen were, respectively, $20.5 \%$ and $7.3 \%$ smaller in cadavers with hernia.

Thus, variations in the amount of collagen and collagen type I/III ratio in the aponeurosis may be associated with abdominal wall hernias. However, no studies were found in the literature assessing collagen content in the rectus abdominis muscle. Therefore, the aim of this study was to assess the collagen content and types in the rectus abdominis muscle of cadavers of different ages.

\section{Methods}

The study was approved by the Research Ethics Committee of UNIFESP (process no. 1492/08) and authorized by the Institute of Legal Medicine of Franca (SP, Brazil). Forty fresh adult male cadavers, at room temperature, were dissected within 24 hours of death. The exclusion criteria were: cadavers under 18 years of age, stored at low temperatures, with previous laparotomy, abdominal wall hernias, or abdominal trauma.

The height, weight, xyphoid-pubis distance, and distance between the iliac crests were measured and the body mass index was calculated.

The cadavers were divided into two groups: Group A ( $\mathrm{n}=$ 20), 18 to 30 years of age (mean 23.45, median 24); and Group B $(n=20), 31$ to 60 years of age (mean 46.25 , median 47.50$)$.
The cadaver was placed in supine position and a xiphoid-to-pubis incision passing around both sides of the umbilicus was made with a scalpel through the skin and superficial fascia until the linea alba was exposed. The supra-aponeurotic dissection was limited superiorly by the coastal margins, bilaterally by the linea semilunaris, and inferiorly by the iliac crests and inguinal ligaments.

The midline between the rectus abdominis muscles was marked with crystal violet. Two sampling points were marked: the first, $3 \mathrm{~cm}$ above the umbilicus (supraumbilical level), and the second, $2 \mathrm{~cm}$ below the umbilicus (infraumbilical level). A $1.5-\mathrm{cm}$ longitudinal incision was made in the anterior rectus sheath and two $1-\mathrm{cm}^{2}$ fragments were dissected from the central portion of each rectus abdominis muscle, one at the supraumbilical level and another from the infraumbilical level, for a total of 4 fragments per cadaver.

The fragments were named as following: ur, upper right; ul, upper left; lr, lower right; and ll lower left. The fragments were coded and then fixed in $10 \%$ buffered formalin, embedded in paraffin, and cut into $3-\mu \mathrm{m}$ sections. Immunohistochemical analysis was performed using rabbit antibody (Novotec, France) diluted in the sequence $1: 50,1: 100,1: 50$, and $1: 100$ to detect type I, II, III, and IV collagen; human stomach/colon was used as a positive control and omission of the primary antibody, as a negative control.

Image acquisition and digitization was performed using a 3.2 megapixel digital camera (Olympus Q-Color3 Imaging System, USA) with 200 dpi resolution coupled to an optical microscope (Olympus). Images were acquired at x 100 magnification from 10 randomly chosen fields.

A scoring system was standardized for the immunohistochemical analysis of collagen content and types present in the histological sections (Table 1).

TABLE 1 - Qualitative evaluation of collagen by immunohistochemical analysis.

\begin{tabular}{ccc}
\hline Classification & Numerical Value & Amount of Collagen \\
\hline 0 & 0 & Absent \\
+ & 1 & Minimal \\
++ & 2 & Moderate \\
+++ & 3 & Abundant \\
\hline
\end{tabular}

Statistical analysis was performed with the Wilcoxon test (comparisons within groups) and Mann-Whitney U test (comparisons between groups). Statistical significance was set at $p \leq 0.05$.

\section{Results}

Immunohistochemical analysis showed that the rectus abdominis muscle contains collagen fibers with different diameters, polygonal sections, and one or more peripheral nuclei.

Immunohistochemical results revealed significantly larger amounts of type I and III collagen in Group A than in Group B, absence of type II collagen in both groups, and similar amounts of type IV collagen in both groups (Figures 1 and 2). 


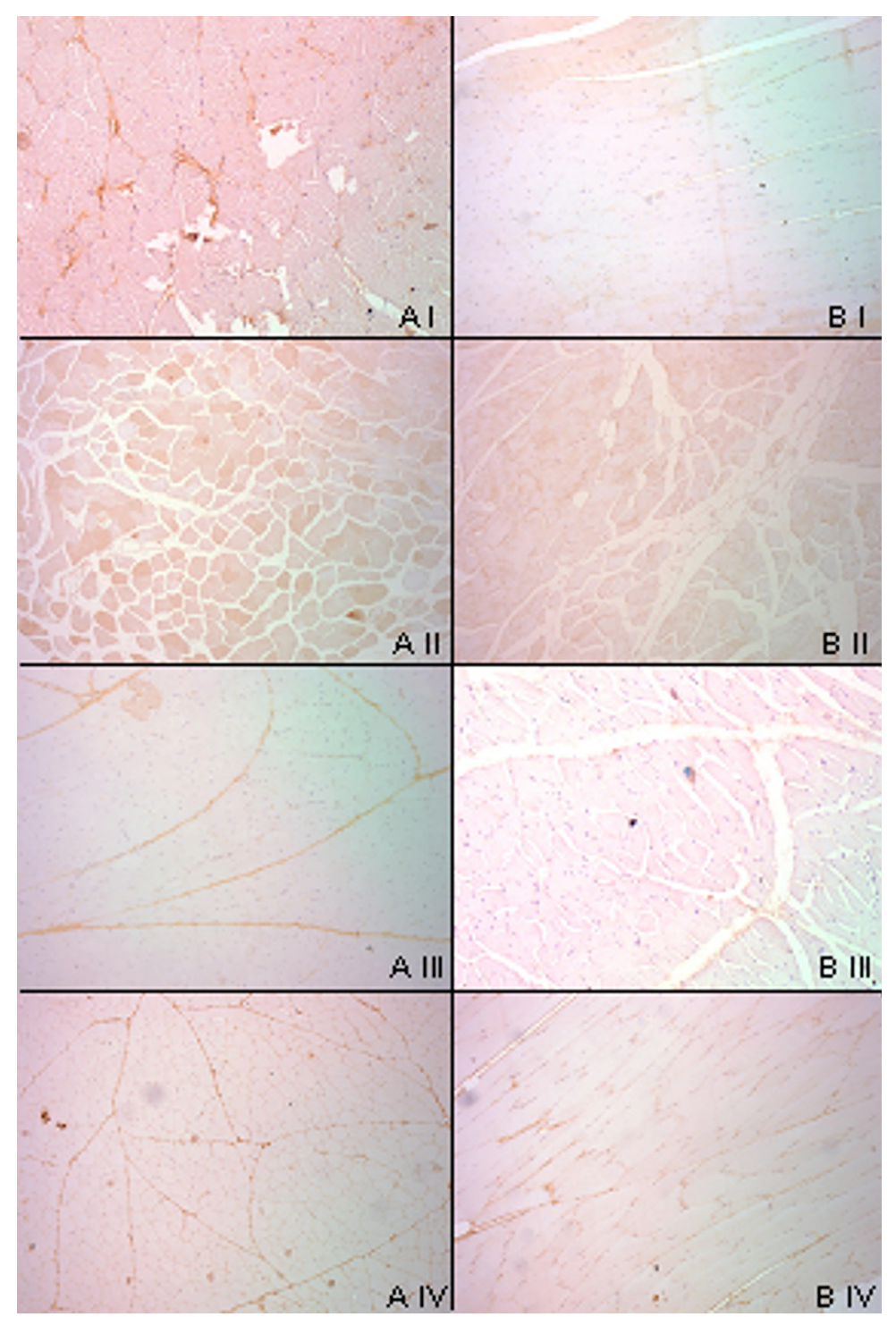

FIGURE 1 - Photomicrographs of collagen in the rectus abdominis muscle. Type I collagen (AI and BI); type II collagen (AII and BII); type III collagen (AIII and BIII); type IV collagen (AIV and BIV) - x100 magnification.

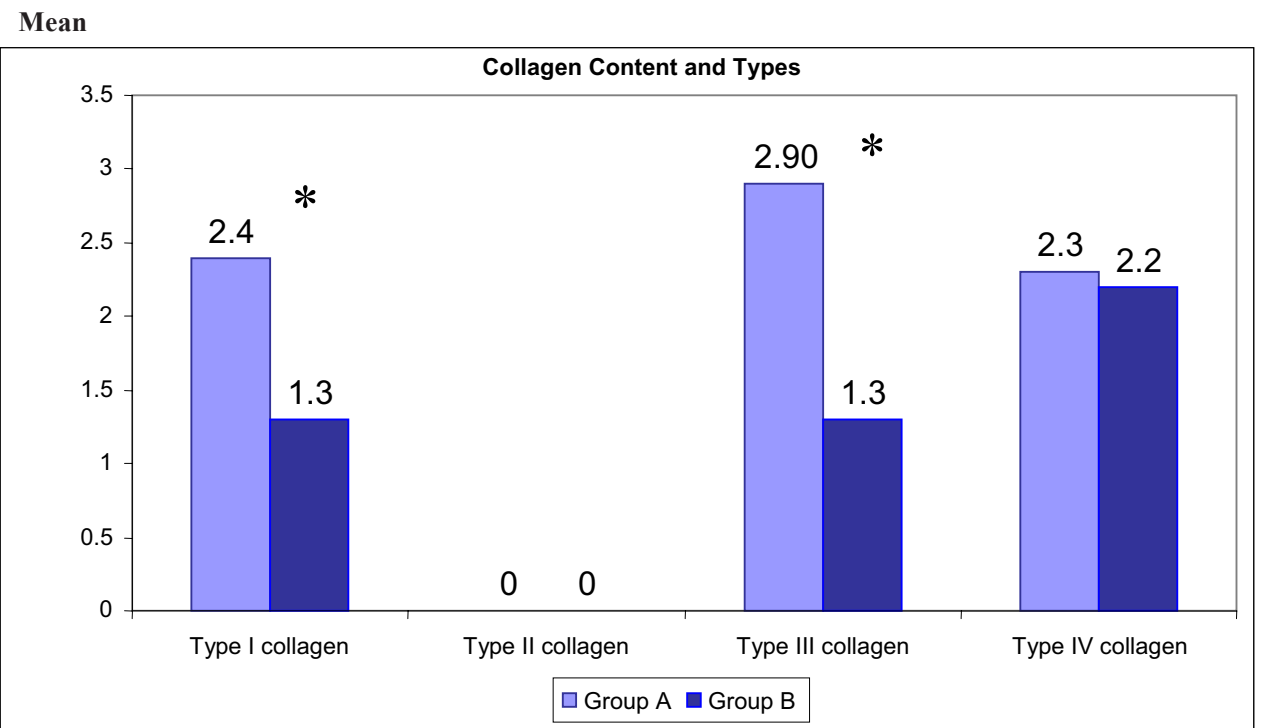

FIGURE 2 - Collagen content and types present in the rectus abdominis muscle for both groups determined by immunohistochemical analysis.

*Statistical significance, $p<0.05$. Mann-Whitney test. 


\section{Discussion}

Because of the high incidence of abdominal wall hernias, a better understanding of the anatomy, physiology, and histology of the structures involved in this condition is needed ${ }^{10}$.

The skeletal striated muscle tissue is composed by two basic types of fibers with different metabolic, morphologic and contractile characteristics ${ }^{11}$. The relative amount and distribution of collagen fibers in the different muscles depends on the species, race, sex, age, muscle group, and on the individual itself. They also depend on the level of physical activity, lack of use, nutrition status, denervation, and chronic physiological stress. In this field of research, morphological and histochemical methods of analysis have been useful in the study of muscle anatomy and physiology ${ }^{12}$.

Although a large number of collagen types have been identified, the exact role of their structural functions in the different tissues of the body, especially in muscles, is still not well established. However, it is known that collagen in striated muscles has a structural function, connecting muscle fibers to ensure that these fibers are properly aligned. The tensile strength of collagen results from the unique structure of its fibers, fibrils, and molecules. More specifically, the tensile strength results from inter- and intramolecular crossed connections, orientation, density, and frictional forces between fibers, and physical and chemical interactions with other structural components of the extracellular matrix $^{13}$.

The evaluation of the subtypes of collagen fibers in muscle biopsies has been essential for the diagnosis of different pathological and experimental conditions, such as hypertrophy caused by repetitive strain and sustained work, muscle atrophy due to lack of use or denervation, and longitudinal fiber splitting ${ }^{11}$.

There are few reports in the literature on the effects of ageing on human muscles, probably because of the difficulties associated with the performance of serial studies in humans, which may be one of the reasons why most of the studies use animal models ${ }^{13-16}$. Because it is difficult to obtain muscle biopsy samples from healthy individuals, we opted to use muscle fragments from cadavers, collected at the same site locations ( $3 \mathrm{~cm}$ above and 2 $\mathrm{cm}$ below the umbilicus) used in previous studies ${ }^{15}$. At these locations, the rectus abdominis muscle is completely surrounded by the muscle sheath. This is important to ensure sample homogeneity, since the amount of collagen may vary over muscle areas not covered by aponeurosis ${ }^{1,15-19}$.

Male gender was used as an inclusion criterion, so that the observations were not affected by the number of pregnancies and possible diastasis recti abdominis, which is more common in women. The cadavers were divided into two groups: the Group A consisted of younger adults (18 to 30 years of age), and Group B consisted of older adults ( 31 to 60 years of age). The maximum age was set at 60 years so that possibly only changes in the functional equilibrium were present in the sample, thus avoiding the effect of senile changes common in older individuals ${ }^{20}$.

Studies in patients and cadavers assessing the amount of collagen in the fascia transversalis and anterior sheath of the rectus abdominis muscle have reported a link between quantitative changes in collagen content and hernia formation, but these studies have not compared different age groups ${ }^{3,21}$. Wolwacz Júnior et al. ${ }^{3}$ did not observe degeneration of collagen fibers in the fascia transversalis associated with senility in patients with hernia. However, in that study, the percent area of collagen in samples of patients with hernia was half of that observed in samples of patients without hernia (controls). In another study, no difference in the concentration of collagen was found between patients with hernias and cadavers without hernias ${ }^{22}$. Immunohistochemical analysis of type I and type III collagen in the skin of 18 patients with $(n=9)$ and without $(n=9)$ inguinal hernia has shown quantitative and qualitative significant differences in collagen fibers and collagen type I/III ratio between groups ${ }^{23}$. Other investigators have reported no significant difference in the amount of collagen in the fascia transversalis of patients with hernia compared with cadavers without hernia, but significantly larger amounts of type III collagen were found in patients with Nyhus type IIIa hernias compared with patients with other types of inguinal hernia ${ }^{22}$. Fachinelli ${ }^{10}$ observed that the amount of total collagen was $18.5 \%$ smaller in patients with anterior abdominal wall hernia compared to cadavers without hernia, and that the amounts of type I and type III collagen were, respectively, $20.5 \%$ and $7.3 \%$ smaller in patients with hernia.

None of the studies found in the literature compared the type and content of collagen in the rectus abdominis muscle of cadavers of different ages. Immunochemical results revealed that there was a significant difference in the amounts of type I and type III collagen between age groups. The results suggest that the muscle strength of the abdominal wall decreases with age, and that there is an increased risk of abdominal hernia formation associated with the fragility of the anatomic structure caused by the reduction in the amount of total collagen.

\section{Conclusion}

The amount of type I and type III collagen, determined by immunochemical analysis, was larger in the cadavers aged between 18 and 30 years compared with cadavers aged between 31 and 60 years.

\section{References}

1. Nahas FX, Ishida J, Gemperli RF, Ferreira MC. Abdominal wall closure after selective aponeurotic incision and undermining. Ann Plast Surg. 1998;41(6):606-13. Discussion 613-7.

2. Si Z, Rhanjit B, Rosch R, Rene PM, Klosterhalfen B,Klinge U. Impaired balance of type I and type III procollagen mRNA in cultured fibroblasts of patients with incisional hernia. Surgery. 2002;131(3):324-31.

3. Wolwacz Júnior I, Trindade MRM, Cerski CT. O colágeno em fáscia transversal de pacientes com hérnia inguinal direta submetidos à videolaparoscopia. Acta Cir. Bras. 2003;18(3):196-201.

4. Henriksen NA, Yadete DH, Sorensen LT, Agren MS, Jorgensen LN. Connective tissue alteration in abdominal wall hernia. Br J Surg. 2011;98(2):210-9.

5. Silva AL, Guerra AJ, Castro MAM. Hérnia incisional. In: Silva AL, editor. Hérnias. 2ed. São Paulo: Roca; 2006. p.398-420.

6. Dubay DA, Wang X, Adamson B, Kuzon WM Jr, Dennis RG, Franz MG. Mesh incisional herniorrhaphy increases abdominal wall elastic properties: a mechanism for decreased hernia recurrences in comparison with suture repair. Surgery. 2006;140(1):14-24.

7. Nahas FX, Barbosa MVJ, Ferreira LM. Factors that may influence failure of the correction of the musculoaponeurotic deformities of the abdomen. Plast Reconstr Surg. 2009; 124:334-5. 
8. Gao Y, Kostrominova TY, Faulkner JA, Wineman AS. Age-related changes in the mechanical properties of the epimysium in skeletal muscles of rats. J Biomech. 2008;41 (2):465-9.

9. Oliveira CC, Teodoro WR, Velosa APP, Yoshinari NH. Auto-imunidade e colágeno V. Rev Bras Reumatol. 2006,46(3): 194-8.

10. Fachinelli A. Avaliação qualitativa e quantitativa do colágeno total, tipo I e III da linha Alba em pacientes portadores de hérnia da parede abdominal anterior [Thesis]. Porto Alegre: Universidade Federal do Rio Grande do Sul; 2005.

11. Britto MKM, Carvalho Junior CG, Dal Pai A, Dal Pai V, Giacometti JA. Morfologia e morfometria dos tipos de fibras do músculo reto abdominal de cadelas (Canis familiaris) durante a gestação. Braz J Vet Res Sci. 2007;44(4):254-60.

12. Orpheu SC, Coltro PS, Scopel GP, Gomez DS, Rodrigues CJ, Modolin ML, Faintuch J, Gemperli R, Ferreira MC. Collagen and elastic content of abdominal skin after surgical weight loss. Obes Surg. 2010;20(4):480-6. 13. Imamura ST, Imamura M, Hirose-Pastor E. Efeitos do envelhecimento e do exercício físico sobre o colágeno do músculo esquelético humano. Rev Bras Reumatol. 1999;39(1):35-40.

14. Silveira RÂB, Nahas FX, Hochman B, Bazzano FCO, Amorim CR, Ferreira LM. Cadaver as an experimental a model for the study of midline incisional hernia. Acta Cir Bras. 2011; 26(4): 310-3.

15. Nahas FX, Ferreira LM. Cadaver as an experimental model to study abdominal wall tension. Acta Cir Bras. 2003;18:37-45.

16. Nahas FX, Kimura AK, Barbosa MV, Juliano Y, Ferreira LM. Components separation technique with limited subcutaneous undermining: a cadáver study. Ann Plast Surg. 2011;67(3):303-8.
17. Amorim CR, Nahas FX, Souza VC, Ely PB, Silveira RA, Novo NF, Ferreira LM. Tensile strength of the posterior and anterior layer of the rectus abdominis muscle sheath in cadavers. Acta Cir Bras. 2007;22(4):255-9.

18. Barbosa MVJ, Nahas FX, Oliveira Filho RS, Ayaviri NAM, Novo NF, Ferreira LM. A variation in the component separation technique that preserves linea semilunaris: a study in cadavers and a clinical case. $\mathrm{J}$ Plast Reconstr Aesthet Surg. 2009; 63(3):524-31.

19. Barbosa MV, Nahas FX, Garcia EB, Ayaviri NA, Juliano Y, Ferreira LM. Use of the anterior rectus sheath for abdominal wall reconstruction: a study in cadavers. Scand J Plast Reconstr Surg Hand Surg. 2007; 41(6):273-7.

20. Silveira RÂB, Nahas FX, Hochman B, Bazzano FCO, Amorim CR, Juliano Y, Passos VM, Ferreira LM. Mapping traction strength of the anterior rectus sheath in cadaver. Acta Cir Bras. 2010; 25(4): 347-9.

21. Gonçalves RO, Silva EM, Marques TC, Lopes Filho GJ. Avaliação histoquímica quantitativa do colágeno na fáscia transversalis e na bainha anterior do músculo reto abdominal em doentes com hérnia inguinal. Rev Col Bras Cir. 2003; 30(4):286-92.

22. Morales PB. Estudio inmunohistoquímico del colágeno tipo I y tipo III en piel de pacientes con hernia inguinal primaria. Rev Chil Cir. 2005;57(6):489-94.

23. Meyer AL, Berger E, Monteiro Jr O, Alonso PA, Stavale JN, Gonçalves MP. Quantitative and qualitative analysis of collagen types in the fascia transversalis of inguinal hernia patients. Arq Gastroenterol. 2007; 44(3):230-4.

\section{Correspondence:}

Prof. Dr. Fábio Xerfan Nahas

Disciplina de Cirurgia Plástica, UNIFESP

Rua Napoleão de Barros, $715 / 4^{\circ}$ andar

04024-0022 São Paulo - SP Brasil

Tel: (55 11) 5083-7152

fisioeliziane@yahoo.com.br

Conflict of interest: none

Financial source: FAPESP

${ }^{1}$ Research performed at the Division of Plastic Surgery, Federal University of Sao Paulo (UNIFESP), Brazil.

Presented at the XII National Congress on Experimental Surgery of the Brazilian Society for the Development of Research in Surgery-SOBRADPEC, 2011, October 26-29 Ribeirao Preto-SP, Brazil. 